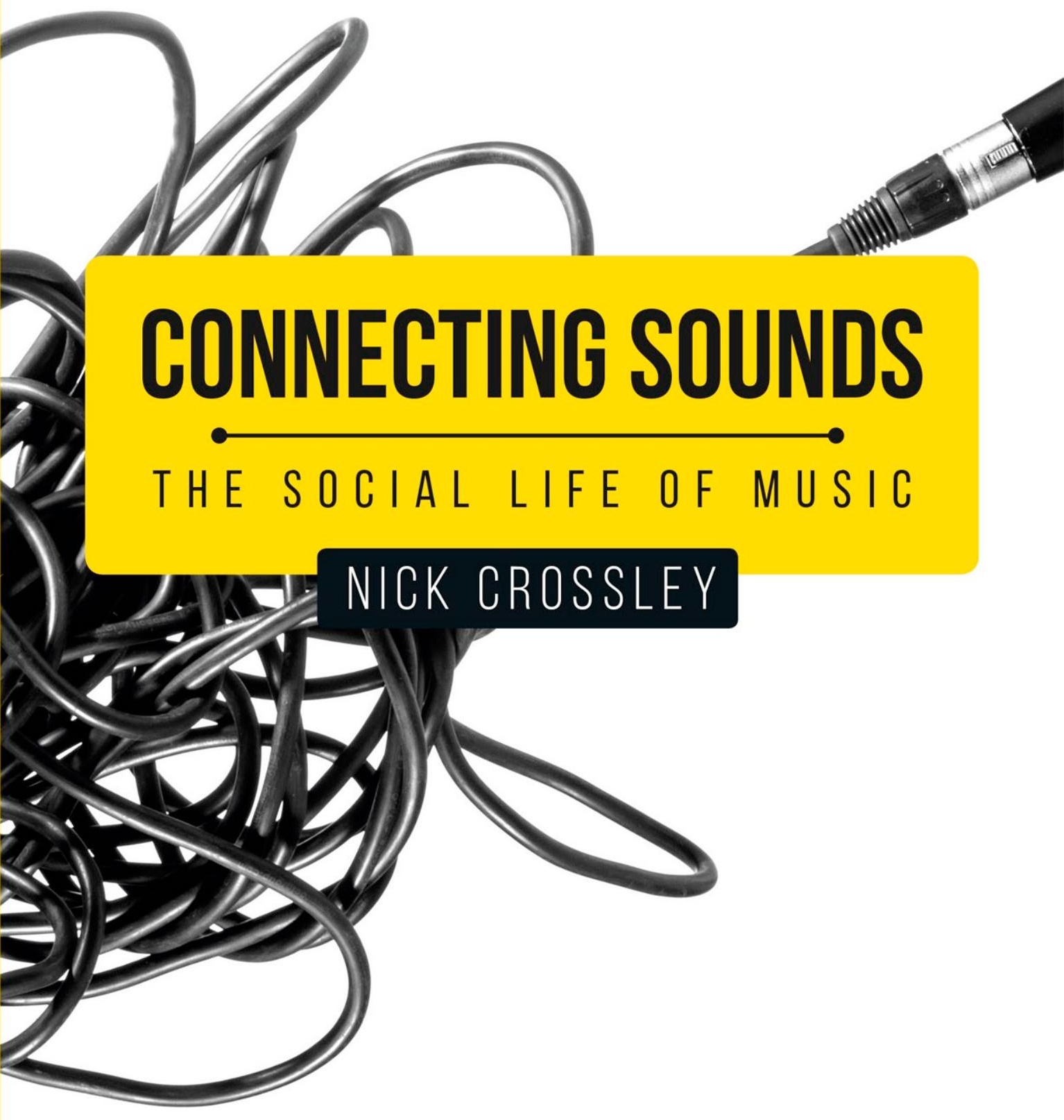




\section{Connecting sounds}

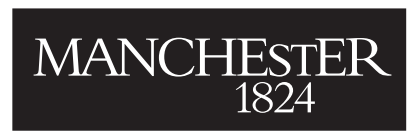

Manchester University Press 
Nick Crossley - 9781526126023 Downloaded from manchesterhive.com at 04/26/2023 10:57:31AM via free access 


\section{Connecting sounds \\ The social life of music}

Nick Crossley

Manchester University Press 
Copyright $\odot$ Nick Crossley 2020

The right of Nick Crossley to be identified as the author of this work has been asserted by him in accordance with the Copyright, Designs and Patents Act 1988.

Published by Manchester University Press

Altrincham Street, Manchester M1 7JA

www.manchesteruniversitypress.co.uk

British Library Cataloguing-in-Publication Data

A catalogue record for this book is available from the British Library

ISBN 9781526126016 hardback

ISBN 9781526126030 paperback

First published 2020

The publisher has no responsibility for the persistence or accuracy of URLs for any external or third-party internet websites referred to in this book, and does not guarantee that any content on such websites is, or will remain, accurate or appropriate.

Cover: istock.com

Typeset

by Toppan Best-set Premedia Limited 